\title{
Mental health literacy of healthcare providers in Arab Gulf countries: a systematic review
}

Rowaida Elyamani ${ }^{1}$, Hamed Hammoud ${ }^{1}$

1 Community Medicine Department, Medical Education Center, Hamad Medical Corporation, Doha, Qatar

Corresponding author

Hamed Hammoud, MD

Community medicine department, Medical education center

Hamad Medical Corporation

Tel: +974-66140605

Email: Hamed0hamoud@gmail.com 


\section{Abstract}

Background: The concept of Mental Health Literacy (MHL) relies on our capacity to understand and recognize mental illnesses and the ability to maintain and promote a positive mentality for ourselves and others. In our review, we aim to examine the level of MHL among healthcare providers in the Arab Gulf States.

Methods: PubMed, PsycINFO, Medline were searched till August 2019. Studies were included if at least one of the main components of mental health literacy was reported, including (a) knowledge of mental illnesses, (b) stigma towards mental illnesses, (c) confidence in helping patients, and (d) behavior of helping patients, regardless of study design. The risk of bias was rated according to the modified Newcastle-Ottawa Quality Assessment Scale for cross-sectional studies.

Results: Seven studies were included in the review; all of them were cross-sectional, with a total of 3516 participants from the healthcare system. Overall most of the studies claimed limited knowledge, negative attitudes, behavior and/or confidence among nurses, pharmacists, and physicians, especially juniors. However, the overall quality of all outcomes was relatively very low.

Conclusions: More high-quality evidence and in-depth qualitative studies are required to bridge the gap between mental health needs and services delivered by healthcare providers in the Gulf Arab region.

Keywords: Mental disorders, health literacy, healthcare workers, stigma, attitude, knowledge 


\section{INTRODUCTION}

Mental health literacy (MHL) was first defined by Jorm AF as "knowledge and beliefs about mental disorders which aid their recognition, management or prevention." ${ }^{1)}$ In 2012, the concept included the ability to provide support to individuals presenting with a mental health problem, and knowing where to seek professional help. ${ }^{(2)}$

MHL is a crucial element for promoting mental health and wellbeing of individuals and populations overall. The significant identified barriers of mental health inlclude lack of knowledge, presence of stigma, and limited access to care. ${ }^{(3)}$ In recent years numerous scholars have highlighted the evidence of association between low MHL and adverse health outcomes and. ${ }^{(4)}$ Mental health problems are considered a global public health challenge that has a greater impact on young adults compared other age groups. Such threats could be tackled early through the promotion of MHL at community and primary care levels. ${ }^{(5,6)}$

The burden of mental disorders in countries of the Eastern Mediterranean Region (EMR) is greater in comparison with other regions around the globe. ${ }^{(7)}$ Hence, the share of mental disorders out of total disease burden in EMR had an increment of more than 10\% between 1990 and 2013 only. ${ }^{(7)}$ Despite this increasing burden; yet, the total expenditure on mental health services in the EMR is relatively low. Arab Gulf countries are categorized as high-income countries in the region. The insufficient allocated budget to mental health, in general, may hinder the promotion of mental health services and meeting the needs of the community. ${ }^{(8)}$

Gulf Cooperation Council (GCC) countries include six states which are, Qatar, Saudi Arabia (KSA), United Arab Emirates (UAE), Oman, Kuwait, and Bahrain. These states are located within the Middle East region, and all are labeled as high-income countries of the area. They all 
share many social, religious, and cultural features. Additionally, GCC countries share a lot of common health challenges and opportunities. ${ }^{(9)}$

Research work on mental health in the Arab region is facing hardship. Results of a systematic review related to research on mental health in EMR found that only two countries from the GCC region had the most publications, namely Saudi Arabia and Kuwait. ${ }^{(10)}$

Literature related mental health topics among health care providers (HCPs) worldwide revealed an existing pattern of stigmatizing attitudes, lack of awareness, and false beliefs regarding patients with mental disorders. ${ }^{(11,12)}$ Evidence also indicated that many practitioners exhibit a common notion of feeling incompetent and discouraged about the management and recovery of individuals who are mentally ill. ${ }^{(13)}$ Scholars also found that the stigmatizing culture continues to happen even within the work environment in health care systems, preventing those among health care providers who suffer mental problems from seeking help and speaking to other colleagues about their issues. ${ }^{(14)}$

There are, indeed, growing numbers of studies tackling the gap between the performance of HCP in mental services and the community needs. Reviews on HCP and their level of MHL in the Arab region has, however, not been reported so far. In our study, we are aiming to assess the level of MHL among health care providers in the Arab Gulf states.

\section{METHODS}

We followed the Preferred Reporting Items for Systematic Reviews and Meta-Analyses (PRISMA) guidelines in conducting this systematic review. ${ }^{(15)}$ Both authors independently searched PubMed, PsycINFO, and Medline for studies published up until August 2019 (without 
earlier date limits). The search strategy included search terms like: "mental disorders," "mental health," "literacy," "Arab," and related terms (see the Appendix).

\section{Inclusion and exclusion criteria}

We included studies that have evaluated MHL among health care providers and published in English, regardless of the study design. The review included studies which quantitatively measured at least one of the main components of MHL as follows: (a) knowledge of mental illnesses and their treatment; (b) stigmatizing attitudes towards mental illnesses; (c) confidence in helping patients with mental health problems and (d) behavior of helping patients. Additionally, any study that may have reported separate findings describing the level of MHL among HCP from a larger population was also considered for review.

\section{Study selection}

Both authors independently screened titles and abstracts and excluded studies that were not relevant to the topic of interest. They independently reviewed full-texts of articles for the final selection of included studies. Any disagreements between the reviewers were resolved by discussion.

\section{Critical appraisal method}

To assess the internal validity of the included studies, the Newcastle-Ottawa Quality Assessment Scale (modified for cross-sectional studies) was used. (16) The tool contains three major subsections (Selection, Comparability, and Outcome). A score for quality, modified from the tool, was used to assess the appropriateness of study design, recruitment strategy, response rate, sample representativeness, reliability of the outcome, sample size provided, and appropriate

statistical analyses. ${ }^{(16)}$ According to the NOS score standard, cross-sectional studies could be 
classified as low-quality (scores of 0-4), moderate-quality (scores of 5-6), and high-quality (scores 27). Both authors independently ranked these domains. When the independent evaluations of the ranks differed between the two reviewers, they discussed disagreements to reach for mutual decision.

\section{The overall quality of outcomes}

The overall quality of the evidence for study outcome was rated as high, moderate, low, or very low, using the Grades of Recommendation, Assessment, Development, and Evaluation

(GRADE) framework. ${ }^{(17)}$ GRADE assesses five domains to determine the evidence level, including study limitations, the inconsistency of results, indirectness of evidence, imprecision, and reporting bias. Quality was also independently rated by the both authors.

\section{Data extraction}

The first author extracted the following data from each included study: country, study design, the time, population, sample size, method of data collection, outcome measures. The second author confirmed the data extracted from each included study.

\section{RESULTS}

Figure 1 is a flow chart showing the procedure for the selection of studies. We identified 341 studies in the initial search of all three databases. We initially screened the titles for all articles and yielded 24 potentially eligible studies, after which we removed 11 duplicates. A total of 13 articles were included for reviewing, however, in the stage of full text reading, three articles were excluded as they didn't meet the inclusion criteria. In addition, another three articles were excluded due to the unavailability of the full text despite contacting the authors. After assessing the fulltexts of the remaining seven studies, it was found that all seven studies met the inclusion criteria. 


\section{Characteristics of studies and participants}

Table 1 summarizes the country of origin, study design, the timing of data acquisition, population, sample size, participant recruitment method, method of collecting data, contents of the outcome. Regarding study design, all studies were cross-sectional in design.

Among included studies, two studies focused on physicians only, and two studies were exclusively about nurses; one study included both physicians and nurses, one study on pharmacists, and one study on other hospital staff excluding the treating doctors for mentally ill patients.

All studies were cross-sectional and used different measurement tools to assess the outcomes. Knowledge of mental illnesses was measured in 4 out of 7 studies, stigma towards mental illnesses was mentioned in five studies, confidence in helping self and others, including patients in only two studies. Only two tools were validated; one to measure knowledge about mental illness, and one designed for stigma. The rest of the questionnaires were not validated.

\section{Quality of evidence}

Overall, and according to the GRADE framework ${ }^{(17)}$, the body of evidence was rated as very low. Regarding the precision and confidence estimate, all the evidence derived from observational studies is classified as low quality. The risk of bias assessment among articles showed that five articles scored $>7,{ }^{(18-22)}$, which is considered as high quality, while the other two articles scored between 5-7 (moderate quality) ${ }^{(23,24)}$ (Table 2). A high degree of inconsistency was noticed in the review as the study populations varied greatly. Publication bias was identified in the review due to multiple reasons, including the selection of published articles and in the English language only. Furthermore, the unfavorable results of negative attitudes towards mental illness might contribute to the hiding of study results, the low number of scholarly activities in mental 
health published in the region, and difficulty accessing the full manuscripts of some articles all increased the risk of publication bias. Regarding the indirectness, different tools have been used to assess mental health literacy with the diverse populations among studies. Hence, the quality of evidence was rated as very low.

\section{Knowledge about mental illnesses}

Four out of the seven studies discussed knowledge as an essential pillar of mental health literacy. ${ }^{(20-22,24)}$ Two of these studies were conducted in Saudi Arabia ${ }^{(21,24)}$, and the other two were done in the UAE. ${ }^{(20,22)}$ The only validated tool that was used to assess knowledge was introduced by Alyateem et al. in both of his studies, where he assessed physicians' knowledge level through a paper-based or online survey using fictional characters in case scenarios and ask physicians about diagnostic criteria different mental disorders. ${ }^{(20)}$ For the remaining studies, questionnaires were not validated; however, they were translated from a validated English tools. Al Atram et al. applied an online survey with 20 questions about mental disorders: 10 for anxiety and 10 for depression. ${ }^{(21)}$ Aldahmashi et al. also used a self-administered questionnaire "generalist perspective about depression occurrence, recognition, and management" as apart of the R-DAQ survey. ${ }^{(24)}$

The group most studied for knowledge on mental disorders was non-psychiatric physicians, including pediatric physicians, general practitioners (GPs), family physicians, and medical residents. ${ }^{(20,21,24)}$ Alyateem et al. found that almost half of the pediatric physicians in his study had limited recognition of mental disorders ranging from $47 \%$ to $54.3 \%$ for post-traumatic syndrome disorder (PTSD) and psychosis, respectively. ${ }^{(20)}$ On the other hand, $\mathrm{Al}$ atram et al. found in his study that family physicians performed well when asked about the criteria they used to identify common mental disorders like anxiety, depression, and PTSD, their performance much 
better compared to GPs and specialists. ${ }^{(21)}$ Aldahmashi et al., in their study, found that the majority of physicians stated that proper management of depression is an important part of managing other health problems. ${ }^{(24)}$

The two studies related to nurses were both conducted by Alyateem et al. ${ }^{(20,22)}$ In the first one, which included nurses working in children hospital; they've found that almost half of the participants were unable to identify of the diagnosis for common mental disorder (53\% correctly diagnosed depression, 47\% correctly diagnosed PTSD, and 54\% correctly diagnosed psychosis). (20) In their second study, Alyateem et al. included school nurses, and they found that less than $50 \%$ of the nurses have been able to correctly identify mental disorders presented (depression, PTSD, Psychosis, and suicidal thoughts). ${ }^{(22)}$

\section{Stigma against mental illnesses}

Five studies chose stigma as a determinant for the level of mental health literacy. (18-24) Three studies were conducted in Saudi Arabia ${ }^{(21,23,24)}$, two were held in Kuwait ${ }^{(18,19)}$, and all of them have used different measurement tools. Two studies: Al-Awadhi et al. and Megiud et al., used the Social Classification and Assessment of attitudes towards the Mental Illnesses (CAMI) scale, which is a self-report nonvalidated 40-statement inventory. ${ }^{(18)}$ Alarifi also selected a nonvalidated 69-items, self-administrative Likert-type questionnaire to assess attitudes toward mental illness. ${ }^{(23)} \mathrm{Al}$ atram et al. disseminated an online survey while Aldahmashi et al. used a self-administered The revised Depression Attitude Questionnaire (R-DAQ) ${ }^{(24)}$

The population included in all five studies were heterogeneous. Two studies focused on non-psychiatric physicians (GPs, specialists, family physicians, and medical residents) ${ }^{(21,24)}$, one among pharmacists ${ }^{(23)}$, one involved nurses ${ }^{(19)}$, and the last study was conducted among nonmedical staff working in psychiatric hospitals. ${ }^{(18)} \mathrm{Al}$-Awadhi et al. determined the mean scores on 
the four subscales of CAMI (Authoritarianism: 2.85, Benevolence: 3.66, Social restrictiveness: 2.97, and Community mental health ideology 3.48), which have reflected nurses' negative attitude toward mentally ill patients. ${ }^{(19)}$ Using the same tool, Megiud et al. found that a large percentage of the study population (nurses and non-medical staff) felt that mentally ill patients were 'insane' and 'dangerous,' indicating their negative attitude towards mental illness. ${ }^{(18)} \mathrm{Al}$ atram et al. found that more than 50 percent of the GPs and specialists possessed a negative attitude towards

psychiatric patients, while family physicians showed a positive attitude. ${ }^{(21)}$ Aldahmashi et al. showed that the majority of non-psychiatric physicians were optimistic, confident in depression management and had a slightly positive attitude towards depression with a mean R-DAQ score of 76. ${ }^{(24)}$ Pharmacists, on the other hand, more promising results with 88 percent of them felt that mental illness was the same as other illnesses. Overall they had endorsed positive attitudes toward mental illness. ${ }^{(23)}$

\section{Self-confidence and efficacy in helping patients with mental illnesses}

Only two papers were set to examine self-efficacy and confidence. ${ }^{(23,24)}$ Both of which were conducted in Saudi Arabia. Alarifi and his team recruited pharmacists, while Aldahmashi et al. chose non-psychiatric physicians. Results showed that less than half of physicians were confident in dealing with patients suffering from depression or the ability to diagnose and manage depressions with suicide risk assessment was the area in which they felt least confident. ${ }^{(24)}$ On the contrary, pharmacists revealed inconsistent self-efficacy in helping patients that varied according to certain factors, including mental illness and their experience. Those in practice for more than 
ten years seemed to be more confident in obtaining a history of mentally ill patients. Anxiety and depression were the highest diseases reported by pharmacists that they fell confident to deal with (History taking $37 \%$ and medication counseling 58\%), while paranoia and panic attacks were the lowest (History taking $20 \%$ and medication counseling 39\%). ${ }^{(23)}$

\section{DISCUSSION}

This systematic review synthesizes the literature on the current situation of MHL among health care providers in the Arab Gulf States. Most of the studies reported limited to a low level of one or more of the main components of MHL, including knowledge, stigma, confidence in helping patients; among physicians, nurses, pharmacists, and other related health care workers. Furthermore, all outcomes were rated as very low, due to the lack of randomized studies and overall moderate ROB; according to the GRADE framework. ${ }^{(17)}$

Knowledge about mental health illness is lacking among the public as well as health care providers in the available literature nowadays, despite the general perception that HCPs are more equipped and sympathizing with patients suffering from mental illnesses. Considering the academic background and professional training of $\mathrm{HCP}$, they are expected to deal with both physical and psychological consequences accompanying mental disorders. Yet, unfortunately, a series of studies revealed that HCPs have limited knowledge in addition to unawareness of common mental disorders. As a part of their community, a large sector of HCPs continues to carry the same false beliefs about mental illness, which is a huge barrier in the successful management

of these illnesses at the community level. ${ }^{(25,26)}$ Our results were similar to findings from a study in Nigeria on the HCP knowledge, beliefs, and attitude towards the mentally ill revealed that the majority of participants thought that mental illnesses are irrecoverable and mostly fatal, and more 
than a third admitted to negatively stigmatizing relatives that may suffer from mental disorders. (27)

Education and training also play a significant role in forming stigmatizing beliefs and attitudes towards mental illnesses among health practitioners. Knaak S, Mantler E, and Szeto A conducted a review in which they presented and comprehensive explanation about the inverse relationship between knowledge skills and stigma among HCP. They found that regardless of the education and experience of individuals in health systems, unless they undergo specialized training to alter previous stigmatizing beliefs and behavior related to mental illnesses, this can lead to inefficient management of the patient's condition. In addition to that, the practitioners may experience adverse emotions, "which can negatively impact patient-provider interactions and quality of care." (28) Similarly, several studies in our current review also demonstrated an insignificant relationship between experience and level of mental health literacy.

Overall, the literature shows that more researches were conducted among primary health care providers as opposed to other more specialized groups within HCP. This likely to be due to the critical role these practitioners in promoting positive mental health in their communities and providing better access to mental health services at the primary level. Unfortunately, more evidence has revealed that even among primary care physicians and general practitioners, a culture of stigmatization and shame are present, which may hinder the efforts to achieving better mental health services to the mentally ill. This is consistent with findings from our study. Moreover, in Zambia, a study showed that primary health caregivers recommend the usage of strains and handcuffs with mentally ill patients, which caused a feeling of discomfort. ${ }^{(29)}$ Another study conducted in China is correlated with our results, where they found that discriminating ideas and stigmatizing attitudes spread widely among primary health care providers. In addition to that, their 
pessimistic beliefs towards the mentally ill lead to decreasing their capabilities in providing adequate mental health services. ${ }^{(30)}$

Most limitations of this review are related to the scarcity of research studies in the region. The review was based on studies obtained from peer-reviewed journals by using scientific databases, so it did not include information from other sources such as grey literature and unpublished reports from educational institutions. Therefore, the evaluations conducted may be at risk of misjudging the quality of studies. Moreover, the risk of bias may be one of the limitations in our review due to the lack of studies on the topic, especially in our region. However, we believe that this is due to social and cultural factors that overpowered the importance of mental health literacy among physicians in this region.

\section{Conclusions}

Over the past years, Arab gulf countries underwent a radical transformation process aimed at building a strong foundation for integrating mental health services and to benchmark international health systems. Several campaigns were launched as well to increase public mental health literacy overall, sometimes focusing on specific diseases such as anxiety and depression. However, creating this ambitious goal requires well-trained health care providers with extensive experience and a stigma-free work environment to achieve the most effective outcome with patients suffering from mental illnesses in the Arab Gulf states. The results from this study indicate, however, that there is a gap between background education and existing knowledge of HCP and the actual situation when it comes to dealing with mental disorders. It is, therefore, essential for Arab gulf states to start developing special programs targeting HCP to assist them in releasing those stigmatizing attitudes and behavior while emphasizing on the role training 
workshops in enhancing their mental health literacy. Although determining the impact of such interventions may be unclear at the beginning, more researches need to be conducted to provide a better understanding.

Funding: This research received no external funding.

Ethical: No ethical approval required.

Patient Consent: Not required.

Conflicts of Interest: The authors declare no conflict of interest. 


\section{References}

1. Jorm AF. Why We Need the Concept of "Mental Health Literacy". Health communication. 2015;30(12):1166-8.

2. Jorm AF. Mental health literacy: empowering the community to take action for better mental health. The American psychologist. 2012;67(3):231-43.

3. Kutcher S, Wei Y, Morgan C. Successful Application of a Canadian Mental Health Curriculum Resource by Usual Classroom Teachers in Significantly and Sustainably Improving Student Mental Health Literacy. Canadian journal of psychiatry Revue canadienne de psychiatrie. 2015;60(12):580-6.

4. Kutcher S, Wei Y, Coniglio C. Mental Health Literacy: Past, Present, and Future. Canadian journal of psychiatry Revue canadienne de psychiatrie. 2016;61(3):154-8.

5. Patel V, Flisher AJ, Hetrick S, McGorry P. Mental health of young people: a global publichealth challenge. Lancet (London, England). 2007;369(9569):1302-13.

6. World Health Organization. Child and adolescent mental health [Internet]. Geneva [30 December 2018]. Available from: https://www.who.int/mental health/maternalchild/child_adolescent/en/.

7. The burden of mental disorders in the Eastern Mediterranean region, 1990-2015: findings from the global burden of disease 2015 study. International journal of public health. 2018;63(Suppl $1): 25-37$.

8. Okasha A, Karam E, Okasha T. Mental health services in the Arab world. World psychiatry : official journal of the World Psychiatric Association (WPA). 2012;11(1):52-4. 
9. Karam E, Itani L. Mental health research in the Arab world: an update. BJPsych International. 2015;12:S-25.

10. Khoja T, Rawaf S, Qidwai W, Rawaf D, Nanji K, Hamad A. Health Care in Gulf Cooperation Council Countries: A Review of Challenges and Opportunities. Cureus. 2017;9(8):e1586.

11. Henderson C, Noblett J, Parke H, Clement S, Caffrey A, Gale-Grant O, et al. Mental healthrelated stigma in health care and mental health-care settings. The lancet Psychiatry. 2014;1(6):46782.

12. Thornicroft G, Rose D, Kassam A. Discrimination in health care against people with mental illness. International review of psychiatry (Abingdon, England). 2007;19(2):113-22.

13. Knaak S, Patten S. A grounded theory model for reducing stigma in health professionals in Canada. Acta psychiatrica Scandinavica. 2016;134 Suppl 446:53-62.

14. Wallace JE. Mental health and stigma in the medical profession. Health (London, England : 1997). 2012;16(1):3-18.

15. Liberati A, Altman DG, Tetzlaff J, Mulrow C, Gotzsche PC, Ioannidis JP, et al. The PRISMA statement for reporting systematic reviews and meta-analyses of studies that evaluate health care interventions: explanation and elaboration. PLoS medicine. 2009;6(7):e1000100.

16. Peterson J, Welch V, Losos M, Tugwell PJOOHRI. The Newcastle-Ottawa scale (NOS) for assessing the quality of nonrandomised studies in meta-analyses. 2011.

17. Schünemann H, Broz 'ek, J., Guyatt, G., \& Oxman, A. (Eds.). GRADE handbook for grading quality of evidence and strength of recommendations. Canada: The GRADE Working Group; 2013 [12-09-2019 [Updated October 2013]]. Available from: https://gdt.gradepro.org/app/handbook/handbook.html. 
18. Rabie M, Marwa A. Meguid, . Stigma \& Attitude toward Mentally Ill among a sample of non-medical staff working in psychiatric Hospitals. Arab journal of psychiatry. 2011;22:55.

19. Al-Awadhi A, Atawneh F, Alalyan MZY, Shahid AA, Al-Alkhadhari S, Zahid MA. Nurses' Attitude Towards Patients with Mental Illness in a General Hospital in Kuwait. Saudi journal of medicine \& medical sciences. 2017;5(1):31-7.

20. Al-Yateem N, Rossiter R, Robb W, Ahmad A, Elhalik MS, Albloshi S, et al. Mental health literacy among pediatric hospital staff in the United Arab Emirates. BMC psychiatry. 2017;17(1):390.

21. Al-Atram AA. Physicians' Knowledge and Attitude towards Mental Health in Saudi Arabia. Ethiopian journal of health sciences. 2018;28(6):771-8.

22. Al-Yateem N, Rossiter RC, Robb WF, Slewa-Younan SJIjomhs. Mental health literacy of school nurses in the United Arab Emirates. 2018;12(1):6.

23. Al-Arifi MN. Community pharmacists attitudes towards mental illness and providing pharmaceutical care for mentally ill patients. Neurosciences (Riyadh, Saudi Arabia). 2008;13(4):412-20.

24. Aldahmashi T, Almanea A, Alsaad A, Mohamud M, Anjum I. Attitudes towards depression among non-psychiatric physicians in four tertiary centres in Riyadh. Health psychology open. 2019;6(1):2055102918820640.

25. Arboleda-Florez J, Stuart H. From sin to science: fighting the stigmatization of mental illnesses. Canadian journal of psychiatry Revue canadienne de psychiatrie. 2012;57(8):457-63.

26. Ungar T, Knaak S, Szeto AC. Theoretical and Practical Considerations for Combating Mental Illness Stigma in Health Care. Community mental health journal. 2016;52(3):262-71. 
27. Ewhrudjakpor C. Knowledge, Beliefs and Attitudes of Health Care Providers towards the Mentally Ill in Delta State, Nigeria. Ethno-Med. 2009;3:19-25.

28. Knaak S, Mantler E, Szeto A. Mental illness-related stigma in healthcare: Barriers to access and care and evidence-based solutions. Healthcare management forum. 2017;30(2):111-6.

29. Kapungwe A, Cooper S, Mayeya J, Mwanza J, Mwape L, Sikwese A, et al. Attitudes of primary health care providers towards people with mental illness: evidence from two districts in Zambia. African journal of psychiatry. 2011;14(4):290-7.

30. Ma Z, Huang H, Nie G, Silenzio V, Wei B. Attitude towards Mental Illness among Primary Healthcare Providers: A Community-Based Study in Rural China. BioMed Research International. 2018;2018:1-6. 
Figure 1 flow chart showing the procedure for selection of studies (PRISMA 2009 Flow Diagram)

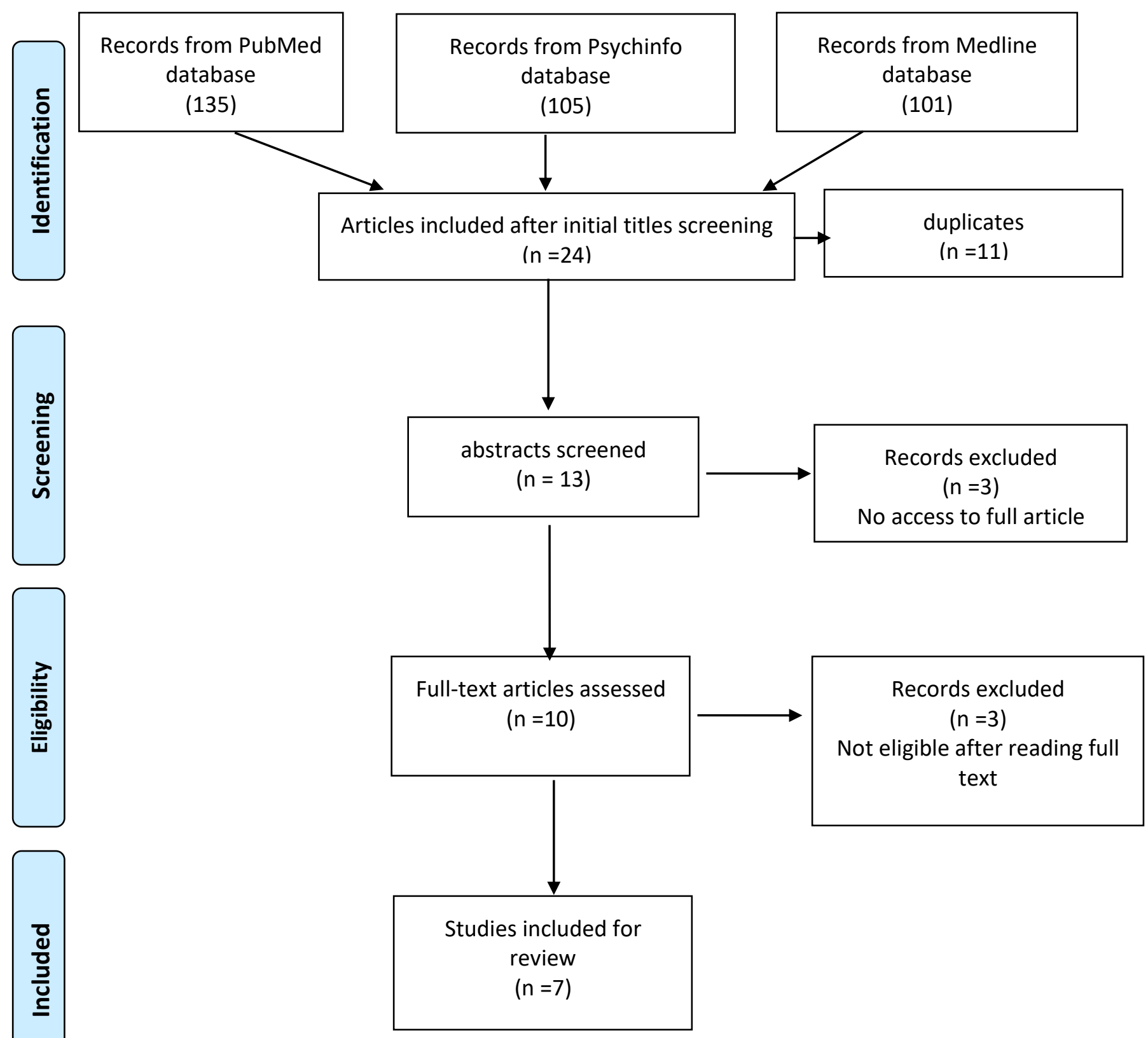


Table 1: General characteristics of the selected studies.

\begin{tabular}{|c|c|c|c|c|c|c|c|c|c|c|c|}
\hline $\begin{array}{l}\text { Authors } \\
\text { (year) }\end{array}$ & aim & country & population & $\begin{array}{l}\text { Sample } \\
\text { size }\end{array}$ & $\begin{array}{l}\text { Sampling } \\
\text { techniques }\end{array}$ & Tools & $\begin{array}{l}\text { Specific } \\
\text { conditions }\end{array}$ & knowledge & stigma & $\begin{array}{l}\text { Self- } \\
\text { efficacy }\end{array}$ & conclusion \\
\hline $\begin{array}{l}\text { 1) Alyateem } \\
2018^{(22)}\end{array}$ & $\begin{array}{l}\text { The primary } \\
\text { aim of this } \\
\text { exploratory } \\
\text { study was to } \\
\text { investigate } \\
\text { school nurses' } \\
\text { level of mental } \\
\text { health literacy } \\
\text { in } \\
\text { relation to } \\
\text { posttraumatic } \\
\text { stress disorder, } \\
\text { depression } \\
\text { with } \\
\text { suicidal } \\
\text { thoughts and } \\
\text { psychosis. }\end{array}$ & $\begin{array}{l}\text { UAE } \\
3 \\
\text { emirates }\end{array}$ & $\begin{array}{l}\text { school } \\
\text { nurses }\end{array}$ & $\begin{array}{l}324 \\
\text { non } \\
\text { response } \\
\text { rate } 40 \%\end{array}$ & convenient & $\begin{array}{l}\text { Self- } \\
\text { administered } \\
\text { validated } \\
\text { questionnaires }\end{array}$ & $\begin{array}{l}\text { PTDS } \\
\text { Depression } \\
\text { and } \\
\text { suicidal } \\
\text { thoughts } \\
\text { psychosis }\end{array}$ & yes & $\mathrm{NO}$ & no & $\begin{array}{l}\text { Significant } \\
\text { number of } \\
\text { respondents } \\
\text { had } \\
\text { difficulty } \\
\text { identifying } \\
\text { specific } \\
\text { disorders } \\
\text { accurately } \\
\text { ( } 49.35 \% \\
\text { correctly } \\
\text { identifying } \\
\text { 'depression } \\
\text { with suicidal } \\
\text { thoughts' } \\
\text { to } 38.6 \% \\
\text { recognition of } \\
\text { 'psychosis'). } \\
\text { At best only } \\
\text { half of } \\
\text { the } \\
\text { respondents } \\
\text { surveyed were } \\
\text { able to identify } \\
\text { a potentially } \\
\text { lethal mental } \\
\text { health disorder } \\
\text { (depression }\end{array}$ \\
\hline
\end{tabular}




\begin{tabular}{|c|c|c|c|c|c|c|c|c|c|c|c|}
\hline & & & & & & & & & & & $\begin{array}{l}\text { with suicidal } \\
\text { thoughts). }\end{array}$ \\
\hline $\begin{array}{l}\text { 2) } \mathrm{Al} \text { atram } \\
(2018)^{(21)}\end{array}$ & & $\begin{array}{l}\text { KSA } \\
\text { Riyad } \\
\text { province }\end{array}$ & $\begin{array}{l}\text { Physicians } \\
\text { GP } \\
\text { Specialists } \\
\text { and family } \\
\text { P }\end{array}$ & $\begin{array}{l}180 \\
\text { Non } \\
\text { response } \\
\text { rate } \\
(21 \%)\end{array}$ & convenient & $\begin{array}{l}\text { Online } \\
\text { surveys } \\
\text { Not validated }\end{array}$ & $\begin{array}{l}\text { Depression } \\
\text { and } \\
\text { anxiety }\end{array}$ & yes & yes & no & $\begin{array}{l}\text { In conclusion, } \\
\text { family } \\
\text { physicians had } \\
\text { a better } \\
\text { knowledge } \\
\text { and positive } \\
\text { attitude to } \\
\text { recognize and } \\
\text { treat anxiety } \\
\text { and depression } \\
\text { than GPs and } \\
\text { specialists. } \\
\text { Attitude a } \\
\text { large number } \\
\text { of participants } \\
\text { in GPs } \\
\text { and specialist } \\
\text { group agreed } \\
\text { with more than } \\
\text { five of } \\
\text { the items that } \\
\text { indicated a } \\
\text { negative } \\
\text { attitude } \\
\text { towards } \\
\text { psychological } \\
\text { problems. O }\end{array}$ \\
\hline $\begin{array}{l}\text { 3) Alyateem } \\
(2017)^{(20)}\end{array}$ & $\begin{array}{l}\text {, this study } \\
\text { aimed to } \\
\text { determine } \\
\text { knowledge of, } \\
\text { and beliefs } \\
\text { about, } \\
\text { helpfulness }\end{array}$ & $\begin{array}{l}\text { UAE } \\
6 \\
\text { emirates }\end{array}$ & $\begin{array}{l}\text { Physicians } \\
\text { and nurses }\end{array}$ & $\begin{array}{l}1400 \\
\text { Non } \\
\text { response } \\
\text { rate } 63 \%\end{array}$ & $\begin{array}{l}\text { Cluster } \\
\text { sampling } \\
\text { technique }\end{array}$ & $\begin{array}{l}\text { Paper based } \\
\text { or online self- } \\
\text { administered } \\
\text { questionnaires } \\
\text { validated }\end{array}$ & $\begin{array}{l}\text { PTDS } \\
\text { Depression } \\
\text { and } \\
\text { suicidal } \\
\text { thoughts } \\
\text { psychosis }\end{array}$ & yes & No & no & $\begin{array}{l}\text { limited } \\
\text { recognition of } \\
\text { mental health } \\
\text { disorders, } \\
\text { ranging from } \\
47 \% \text { for }\end{array}$ \\
\hline
\end{tabular}




\begin{tabular}{|c|c|c|c|c|c|c|c|c|c|c|c|}
\hline & $\begin{array}{l}\text { of treatment } \\
\text { interventions } \\
\text { and providers } \\
\text { of care for } \\
\text { three common } \\
\text { mental health } \\
\text { conditions } \\
\text { (posttraumatic } \\
\text { stress disorder } \\
\text { [PTSD], } \\
\text { depression } \\
\text { with suicidal } \\
\text { thoughts, and } \\
\text { psychosis) } \\
\text { among } \\
\text { healthcare } \\
\text { professionals } \\
\text { working in } \\
\text { pediatric } \\
\text { hospital } \\
\text { settings in the } \\
\text { UAE }\end{array}$ & & & & & & & & & & $\begin{array}{l}\text { PTSD to } \\
54.3 \% \text { for } \\
\text { psychosis. } \\
\text { Approximately } \\
\text { half of the } \\
\text { participants } \\
\text { were unable to } \\
\text { correctly } \\
\text { identify the } \\
\text { disorders } \\
\text { described in } \\
\text { the vignettes. }\end{array}$ \\
\hline $\begin{array}{l}\text { 4) } \\
\text { Aldahmashi } \\
(2019)^{(24)}\end{array}$ & $\begin{array}{l}\text { The aims of } \\
\text { this study were } \\
\text { to explore the } \\
\text { attitudes of } \\
\text { non- } \\
\text { psychiatric } \\
\text { physicians, } \\
\text { assess their } \\
\text { professional } \\
\text { confidence, } \\
\text { therapeutic } \\
\text { optimism and } \\
\text { perspectives } \\
\text { regarding }\end{array}$ & $\begin{array}{l}\text { KSA } \\
\text { Riyad }\end{array}$ & $\begin{array}{l}\text { Non } \\
\text { psychiatric } \\
\text { physicians } \\
\text { Medical } \\
\text { residents }\end{array}$ & 380 & convenient & $\begin{array}{l}\text { self- } \\
\text { administered } \\
\text { questionnaire } \\
\text { Not validated } \\
\text { Arabic } \\
\text { version }\end{array}$ & depression & yes & yes & yes & $\begin{array}{l}\text { Overall, } \\
\text { physicians } \\
\text { were } \\
\text { optimistic, } \\
\text { confident in } \\
\text { depression } \\
\text { management } \\
\text { and held } \\
\text { positive } \\
\text { attitudes } \\
\text { towards } \\
\text { patients with } \\
\text { depression. }\end{array}$ \\
\hline
\end{tabular}




\begin{tabular}{|c|c|c|c|c|c|c|c|c|c|c|c|}
\hline & $\begin{array}{l}\text { depression and } \\
\text { its care using } \\
\text { the R-DAQ. }\end{array}$ & & & & & & & & & & \\
\hline $\begin{array}{l}\text { 5) Alawadhi } \\
(2017)^{(19)}\end{array}$ & $\begin{array}{l}\text { What are the } \\
\text { nurses' } \\
\text { attitudes } \\
\text { toward mental } \\
\text { illness? }\end{array}$ & Kuwait & nurses & $\begin{array}{l}990 \\
\text { Non } \\
\text { response } \\
\text { rate } 69 \%\end{array}$ & convenient & $\begin{array}{l}\text { Self- } \\
\text { administered } \\
\text { questionnaire } \\
\text { Validated and } \\
\text { reliable }\end{array}$ & $\begin{array}{l}\text { No } \\
\text { specific } \\
\text { diseases }\end{array}$ & no & yes & no & $\begin{array}{l}\text { Our results } \\
\text { showed that } \\
\text { the nurses' } \\
\text { attitudes } \\
\text { toward mental } \\
\text { illness were } \\
\text { generally } \\
\text { negative. }\end{array}$ \\
\hline $\begin{array}{l}\text { 6) Alarifi } \\
\text { (2008) }{ }^{(23)}\end{array}$ & $\begin{array}{l}\text { To examine } \\
\text { the attitudes of } \\
\text { community } \\
\text { pharmacist to } \\
\text { both mental } \\
\text { illness and } \\
\text { provision of } \\
\text { pharmaceutical } \\
\text { care. }\end{array}$ & KSA & Pharmacists & $\begin{array}{l}43 \\
\text { Non- } \\
\text { Response } \\
\text { rate 39\% }\end{array}$ & convenient & $\begin{array}{l}\text { Self- } \\
\text { administered } \\
\text { questionnaire } \\
\text { not validated }\end{array}$ & $\begin{array}{l}\text { No } \\
\text { specific } \\
\text { diseases }\end{array}$ & no & yes & yes & $\begin{array}{l}\text { Forty-three } \\
\text { pharmacists } \\
\text { participated in } \\
\text { the study. } \\
\text { Eighty-eight } \\
\text { percent of the } \\
\text { pharmacists } \\
\text { felt that mental } \\
\text { illness was the } \\
\text { same as other } \\
\text { illnesses. } \\
\text { Sixty-six } \\
\text { percent of the } \\
\text { respondents } \\
\text { "strongly } \\
\text { agree," or } \\
\text { "agree" that } \\
\text { mentally ill } \\
\text { patients were } \\
\text { easily } \\
\text { recognizable. } \\
\text { Thirty-three } \\
\text { percent of the } \\
\text { respondents } \\
\text { "disagree }\end{array}$ \\
\hline
\end{tabular}




\begin{tabular}{|l|l|l|l|l|l|l|l|l|l|l|}
\hline 7) Rabie & $\begin{array}{l}\text { we attempted } \\
\text { to assess } \\
\text { beliefs, } \\
\text { attitudes and } \\
\text { behavior of the } \\
\text { community } \\
\text { working in } \\
\text { close contact } \\
\text { with the } \\
\text { mentally ill } \\
\text { patients other } \\
\text { than their } \\
\text { treating } \\
\text { doctors. }\end{array}$ & $\begin{array}{l}\text { Healthcare } \\
\text { workers } \\
\text { except } \\
\text { doctors }\end{array}$ & $\begin{array}{l}199 \\
\text { Non } \\
\text { response } \\
\text { rate }\end{array}$ & randomized & $\begin{array}{l}\text { Self- } \\
\text { administered } \\
\text { questionnaire } \\
\text { Not validated }\end{array}$ & $\begin{array}{l}\text { No } \\
\text { specific } \\
\text { diseases }\end{array}$ & no & yes & no & \\
& & & & & & & & \\
\hline
\end{tabular}


Table 2: Quality assessment of the selected studies using Newcastle-Ottawa Scale (NOS).

\begin{tabular}{|c|c|c|c|c|c|c|c|c|}
\hline \multirow[b]{2}{*}{ Study } & \multicolumn{4}{|c|}{ Selection } & \multirow[b]{2}{*}{$\begin{array}{l}\text { Comparability } \\
\text { Control of } \\
\text { Confounders } \\
\text { (Up to 2 stars) } \\
\text { a) The study controls } \\
\text { for the most important } \\
\text { factor (select one). * } \\
\text { b) The study control } \\
\text { for any additional } \\
\text { factor. * }\end{array}$} & \multicolumn{2}{|c|}{ Outcome } & \\
\hline & $\begin{array}{l}\text { Representativeness } \\
\text { of the sample } \\
\text { a) Truly } \\
\text { representative of the } \\
\text { average in the target } \\
\text { population. * } \\
\text { b) Somewhat } \\
\text { representative of the } \\
\text { average in the target } \\
\text { population. * } \\
\text { c) Selected group of } \\
\text { users. } \\
\text { d) No description of } \\
\text { the sampling } \\
\text { strategy. }\end{array}$ & $\begin{array}{l}\text { Sample size } \\
\text { a) Justified } \\
\text { and } \\
\text { satisfactory.* } \\
\text { b) Not } \\
\text { justified. }\end{array}$ & \begin{tabular}{l}
\multicolumn{1}{c}{ Non- } \\
respondents \\
a) The \\
response rate \\
is \\
satisfactory.* \\
b) The \\
response rate \\
is \\
unsatisfactory \\
c) No \\
description of \\
the response \\
rate
\end{tabular} & $\begin{array}{l}\text { Risk factor } \\
\text { assessment } \\
\text { a) Validated } \\
\text { measurement } \\
\text { tool. ** } \\
\text { b) Non- } \\
\text { validated } \\
\text { measurement } \\
\text { tool, but the } \\
\text { tool is } \\
\text { available or } \\
\text { described. * } \\
\text { c) No } \\
\text { description of } \\
\text { the } \\
\text { measurement } \\
\text { tool. }\end{array}$ & & \begin{tabular}{l}
\multicolumn{1}{c}{ Outcome } \\
Assessment \\
a) Validated \\
measurement \\
tool. ** \\
b) Non- \\
validated \\
measurement \\
tool, but the \\
tool is \\
available or \\
described. ** \\
c) self- \\
reporting \\
outcome. * \\
d)No \\
description of \\
the \\
measurement \\
tool.
\end{tabular} & $\begin{array}{l}\text { Statistical test } \\
\text { a) The statistical test } \\
\text { used to analyze the } \\
\text { data is clearly } \\
\text { described and } \\
\text { appropriate. * } \\
\text { b) The statistical test } \\
\text { is not appropriate, } \\
\text { not described or } \\
\text { incomplete. }\end{array}$ & $\begin{array}{l}\mathscr{2} \\
\stackrel{0}{0} \\
\stackrel{0}{\rho} \\
\stackrel{\rho}{\theta}\end{array}$ \\
\hline $\begin{array}{l}\text { 1) Al-Arifi, KSA } \\
(2008)^{(23)}\end{array}$ & No & No & Yes* & Yes* & Yes* & Yes** & No & 5 \\
\hline $\begin{array}{l}\text { 2) Rabie, Kuwait, } \\
\text { Egypt (2011) }\end{array}$ & Yes* & Yes* & Yes* & Yes* & Yes* & Yes** & Yes* & 9 \\
\hline $\begin{array}{l}\text { 3) Al-Awadhi, } \\
\text { Kuwait (2017) }\end{array}$ & Yes* & Yes* & No & Yes** & Yes* & Yes** & Yes* & 8 \\
\hline $\begin{array}{l}\text { 4) Al-Yateem, } \\
\text { UAE (2017) }\end{array}$ & Yes* & Yes* & No & Yes** & Yes** & Yes** & Yes* & 9 \\
\hline $\begin{array}{l}\text { 5) Al-Atram KSA } \\
\text { (2018) }\end{array}$ & Yes* & No & Yes* & Yes* & Yes* & Yes** & Yes* & 7 \\
\hline
\end{tabular}




\begin{tabular}{|l|c|c|c|c|c|c|c|}
\hline $\begin{array}{l}\text { 6) Al-Yateem, } \\
\text { UAE (2018) }\end{array}{ }^{(22)}$ & Yes* & No & No & Yes** & Yes** & Yes** & Yes* \\
\hline $\begin{array}{l}\text { 7) Aldahmashi, } \\
\text { KSA } \\
(2019)\end{array}$ & No 24$)$ & Yes* & No & Yes* & Yes* & Yes** & Yes* \\
\hline
\end{tabular}




\section{Appendix: PUBMED SEARCH.}

\begin{tabular}{|c|c|c|c|c|}
\hline \multirow[t]{2}{*}{ Database } & \multirow[t]{2}{*}{ Search limitation } & \multirow[t]{2}{*}{ Concept } & \multicolumn{2}{|r|}{ Search Term/strategy } \\
\hline & & & Mesh & Keywords \\
\hline \multirow[t]{3}{*}{ PubMed } & \multirow[t]{3}{*}{$\begin{array}{l}\text { Up to August } 2019 \\
\text { Adult } \\
\text { English } \\
\text { Search field: title, } \\
\text { abstract and full text }\end{array}$} & $\# 1$ & $\begin{array}{l}\text { "Health Literacy" OR "Health } \\
\text { Knowledge, Attitudes, Practice" } \\
\text { OR "Help-Seeking Behavior" OR } \\
\text { "Attitude to health" OR "Social } \\
\text { Stigma" }\end{array}$ & $\begin{array}{l}\text { "Mental Health Literacy" OR "Mental health } \\
\text { awareness" OR "Health knowledge" OR Knowledge } \\
\text { OR "Mental Disorders Literacy" OR "Mood Disorders } \\
\text { Literacy" OR "Depression Literacy" OR "Depressive } \\
\text { Disorders Literacy" OR "Anxiety Literacy" OR } \\
\text { "Bipolar Literacy" OR "Help seeking behaviour" OR } \\
\text { "Help Seeking Behavior" OR "health seeking } \\
\text { behaviour" OR "health seeking behavior" OR } \\
\text { "seeking help" OR "help seeking" OR "Stigmatizing } \\
\text { attitude" OR "Stigmatizing attitudes" OR "stigma* } \\
\text { attitude*" OR "Attitude to health" OR percept* OR } \\
\text { Believes }\end{array}$ \\
\hline & & $\# 2$ & $\begin{array}{l}\text { "Mental Disorders" OR “Anxiety } \\
\text { Disorders" OR "Depressive } \\
\text { Disorder" OR "Mood Disorders" } \\
\text { OR “Bipolar and Related } \\
\text { Disorders" }\end{array}$ & $\begin{array}{l}\text { "Disorder, Mental" OR "mental disorder*” OR } \\
\text { "mental illness*” OR "Mood Disorder*” OR } \\
\text { "Depressive Disorder*” OR depression OR Depressi* } \\
\text { OR “anxiety disorder*” OR anxiety OR schizophrenia } \\
\text { OR “obsessive compulsive disorder*” OR "Bipolar } \\
\text { disorders" OR dementia OR "Alzheimer disease" OR } \\
\text { Alzheimer }\end{array}$ \\
\hline & & $\# 3$ & $\begin{array}{l}\text { "Qatar" OR "Saudi Arabia” OR } \\
\text { "Kuwait" OR "Oman" OR } \\
\text { "United Arab Emirates" OR } \\
\text { "Bahrain" }\end{array}$ & $\begin{array}{l}\text { "GCC countries" OR "Gulf council countries" OR } \\
\text { "Arab states" OR "Middle East" OR Qatar OR Bahrain } \\
\text { OR Oman OR Kuwait OR Saudi Arabia OR KSA OR } \\
\text { "United Arab Emirates" OR UAE OR Arab* }\end{array}$ \\
\hline
\end{tabular}

\#1 AND \#2 AND \#3 